\title{
Surface analysis of the verbal cluster in Dutch*
}

\author{
SIMON VAN DREUMEL and PETER-ARNO COPPEN
}

\section{Abstract}

In this paper, a structuralist account of the verbal cluster of Dutch is given, as implemented in a structuralist surface parser. The description is based on a general principle of expectation, but with a limited number of deviations from the general scheme. It is shown that the implemented parser is able to analyze all clusters, slightly overgenerating to capture those cases where semantic restrictions may apply. In conclusion, it is claimed that the parser incorporates the most complete description of the Dutch verbal cluster so far.

\section{The Dutch verbal cluster}

One of the major issues in Dutch syntax is the analysis of the verbal cluster, that is, the group of verbs that occurs at the end of the clause, generally resisting intervening nonverbal elements, and followed only by elements that can be argued to have been extraposed. In this article, we aim to provide a full description of the Dutch verbal cluster, with an eye to its implementation in a surface-structure parser called Amazon. ${ }^{1}$ In this section, we define the verbal cluster, taking various analyses found in previous research as a starting point. With this definition, we narrow down the constructions to be covered in our discussion.

The distributional facts of the verbal cluster in Dutch look deceivingly simple: verbs taking nonfinite verbal complements in Dutch surface at the end of the clause, ${ }^{2}$ where the verbal complements in general ${ }^{3}$ follow the selecting verbs. As to the arguments of the verbal complements, different verbs allow for different distributions: either all arguments can (or must) be placed adjacent to their governing verb, or all (or some) arguments can (or must) be placed in front of all other verbs: 
(1) ... omdat ik wil proberen [[met iedereen] [rekening] te because I want try [[for everyone] consideration] to houden] show]

'... because I want to try to show consideration for everyone'

(2) ... omdat ik [met iedereen] [rekening] wil proberen [te because I [for everyone] [consideration] want try [to houden] show]

(3) ... omdat ik [met iedereen] wil proberen [[rekening] te because I [for everyone] want try [[consideration] to houden] show]

The arguments met iedereen and rekening are arguments of the verb houden, which in turn forms the complement of proberen. The verb houden always occurs to the right of proberen, while the arguments of houden are placed somewhere to its left.

Despite this distributional simplicity, the transformational analysis for these facts is generally more complex. The construction in (1) is usually considered as a sentential verbal complement that takes the postverbal position, either as a result of an extraposition transformation (from a basic OV structure), or because it remains in situ (in a basic VO structure), For the other two constructions, two analyses exist, which are sometimes combined. One analysis departs from the basic extraposition structure and uses some scrambling process to move the arguments into the matrix clause. The other analysis, generally departing from an OV basic structure, raises the complement verb, possibly accompanied by a limited number of arguments, and right-adjoins it to the selecting verb. The latter approach is known under a variety of names: verb (projection) raising (Evers 1975; Den Besten and Edmondson 1983; Haegeman and Van Riemsdijk 1986; Den Besten 1986, Den Besten et al. 1988; Den Besten and Rutten 1989; Den Besten 1989; Den Besten and Broekhuis 1989; Vanden Wyngaerd 1989; Den Besten and Broekhuis 1990, 1992; Coppen and Klein 1992; Broekhuis 1993; Zwart 1993; Broekhuis 1997), predicate raising (Seuren 1973, 1996), restructuring, reanalysis, and group formation (Haeseryn et al. 1997).

Although it is evident that one of these approaches would suffice to generate the word orders in (1)-(3), some researchers use them both. They claim that the two processes generate surface structures with different syntactic properties. Several criteria are proposed to distinguish between the two. In general, they amount to two properties: 
- The raising process leads to one, inseparable verbal group, that can be moved, nominalized, or coordinated. Extraposition (with or without scrambling) leads to distinct verbal clusters. In German linguistics, the two results are named coherent (kohärent) and noncoherent (inkohärent), respectively (cf. Bech 1955). For an elaborate overview, and some critical remarks concerning the analysis of the German verbal group, see Richter (2000).

- The raising process incorporates some process of clause union: the collected arguments of all verbs behave like the arguments of one single verb; incompatible adverbial elements (like double negation) are excluded. The result of the extraposition process seems to indicate different clauses; each clause has its own adverbials, and adverbials from different clauses may be incompatible.

In this article we are concerned with the first property: the fact that some constructional process leads to a coherent verbal cluster. The description of this cluster is our main aim. Since the exact distinction between the verbal cluster and extraposition structure is subject to some debate, we take a practical stand in this discussion to begin with. We take a sequence of verbal (and nonverbal) elements to be a group if (and only if) no adverbials can intervene. This is in accordance with the distributional facts in Standard Dutch, which allows only verb particles and some predicate complements to enter the verbal end group. Although exceptions to this general principle are found in variants of Dutch, which also allow for nominal complements (and possibly adverbials) to appear in the verbal cluster, the Standard Dutch variant is well defined and uncontroversial. We take the Standard Dutch variant as the core grammar and choose to describe variants as deviations from a general case.

This moderate aim implies that we will not be trying to provide a deeper explanation of the data. Instead, we will be aiming at complete coverage in terms of a coherent grammatical description, that is, the Amazon grammar. To our knowledge, no other study has so far achieved a complete description. Some of the facts mentioned in this article remain unaccounted for in all theories (e.g. the phenomena in section 2.3).

Within the field of natural language processing, parsing the Dutch verbal cluster has long been considered problematic, since the group formation of verbs gives rise to crossing dependencies (Bresnan et al. 1983). The result of a verbal group formation with several arguments is in general schematically as follows:

(4) $\operatorname{Arg}_{a 1} \operatorname{Arg}_{a 2} \operatorname{Arg}_{b 1} \operatorname{Arg}_{b 2} \ldots V_{a} V_{b}$

(5) ... omdat $\operatorname{Jan}_{a 1} \operatorname{Karel}_{b 1}$ Marie $_{b 2} \operatorname{zag}_{a} \operatorname{kussen}_{b}$

because John Charles Mary saw kiss

'... because John saw Charles kiss Mary' 
In this surface order, the relations between verbs and arguments are crossing rather than nesting. This is a complex configuration, because it has been shown that these kinds of structures cannot be adequately described with context-free grammars (Bresnan et al. 1983). It is impossible to describe in a context-free grammar both the relationships and all grammatical strings of a language with crossing dependencies.

However, this parsing problem does not exist within the descriptional context that we aim at. Since we only try to describe the verbal cluster as a surface structure, making no attempt to arrive at a functional analysis of the sentence parts, the crossing dependencies do not arise. The functional dependency of arguments on their verbs is a matter that has to be dealt with by subsequent modules ${ }^{4}$ to the Amazon parser.

Although it seems that we circumvent the real problems in doing this, it is evident that the mere description of the surface structure of the verbal cluster is a useful enterprise. For example, it can be shown that the surface level is a realistic level in human sentence processing:

$$
\text { ... omdat ik Jan Karel wil helpen leren zwemmen }
$$
because I John Charles want help teach swim

'... because I want to help John to teach Charles (how) to swim'

*... omdat ik Jan Karel Marie wil helpen leren zwemmen because I John Charles Mary want help teach swim

*... omdat ik Jan Karel wil helpen geleerd zwemmen because I John Charles want help taught swim

Every native speaker of Dutch will immediately recognize (8) as an ungrammatical sentence. However, the distinction between (6) and (7) is much harder to perceive. In fact, almost no Dutch speaker will be able to recognize the ungrammaticality of (7) within a few seconds. This is because the ungrammaticality of (8) is a surface-structure ungrammaticality, whereas (7) is wrong on a functional level. The Amazon parser aims at describing the ungrammaticality of (8), and it leaves the rejection of (7) to subsequent modules.

Amazon is based on structuralist grammars (Rijpma and Schuringa 1968; Haeseryn et al. 1997) that divide the Dutch clause into five parts: two verbal "poles," 5 two peripheral parts (a topicalization field and an extraposition field), and an intervening "middle field" (Van Dreumel 2000). In the next section, we describe how the verbal cluster is described in the Amazon parser.

\section{The Amazon parsing algorithm for verbal clusters}

In Van Bakel (1975), an algorithm is introduced to describe verbal groups. The algorithm makes use of the concept of expectation, which is 
in fact derived from the traditional notion government (Richter 2000). Verbs typically govern other verbs, in the sense that the former determine the surface forms of the latter.

(I) Analysis of verbal expectation

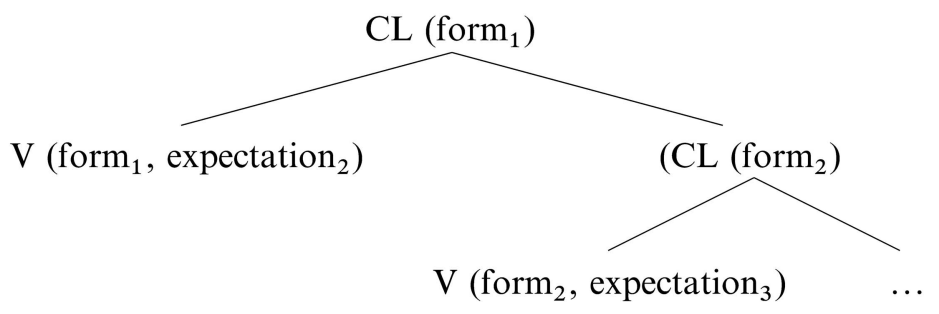

For example, perfective auxiliaries in Dutch (e.g. hebben 'have') require the next verb to be a past participle (e.g. gegeven 'given'). In contrast, some aspectual auxiliaries (e.g. zitten 'sit') ask for an infinitive verb with an infinitival marker te (e.g. te tekenen 'to draw'). In 1975, Van Bakel formulated these dependencies in a syntax-embedded parser as expectations: the parser that encountered an aspectual auxiliary such as zitten changed to a state expecting an infinitive with te. In turn, such an infinitive could give rise to other expectations. Upon encounter with a verb form that would generate no new expectation, the parser would signal the end of the verbal cluster.

The following example illustrates the working of the algorithm:

... zou willen kunnen zitten te slapen
[INF] [INF] [INF] [te + INF] [ ]
should want can sit to sleep
'should want to be able to sit and sleep'

In this example, zou, willen, and kunnen all generate the expectation of an infinitive. The verbs willen, kunnen, and zitten all meet these expectations. The verb zitten in turn creates the expectation of an infinitive with te, which is met by te slapen. Being a main verb, slapen does not generate an expectation, and the cluster is closed.

It is evident that Dutch verbs may be ambiguous in their expectation possibilities. For example, hebben may also be followed by an infinitive with te (roughly corresponding to the English have to). This does not affect the algorithm, though, because it can be treated as lexical ambiguity.

Van Bakel (1975) found three deviations from the general scheme: the infinitivus pro participio (IPP) effect, alternatively placed past participles, 
and infinitival inversion. We will discuss these in sections 2.1, 2.2, and 2.4 respectively.

In Coppen (1987), the original Amazon algorithm is converted into a context-free grammar formalism, which makes use of affix unification. In doing so, what was first a parser heuristic is reformulated as a grammatical description. The technique is simple. Both the verbal form and the verbal expectation are coded into affix positions expanded by unification $^{6}(\mathrm{CL}=$ verbal cluster; cf. Table 1$)$ :

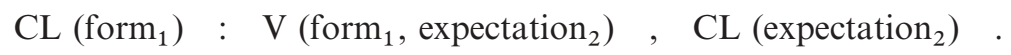

In our analysis, we have essentially used this strategy. However, as we found more deviations from the general scheme, we found reason to slightly enhance the verb-form coding of Coppen (1987).

In Table 1, an overview is given of the verb-form codings used in the current Amazon grammar. The finite form of a verb is the verbal form that agrees with the subject. It is marked by person, number, and tense. The past participle and present participle are degenerate, almost adjectival forms. The infinitival marker te can be argued to belong to the verb form, since it is the only "word" that may appear between verb stems and verb particles:

$$
\begin{aligned}
& \text { we proberen door te lopen } \\
& \text { we try through to walk } \\
& \text { 'we try to walk on' } \\
& \text { *we kunnen door niet lopen } \\
& \text { we can through not walk } \\
& \text { 'we cannot walk on' }
\end{aligned}
$$

Table 2 gives an overview of verbal expectations. These are not identical to the verbal forms. For example, a verb may take the form of a present participle, but in Modern Dutch there is no auxiliary creating the expectation for a present participle. ${ }^{7}$ In addition, although there is only one verb

Table 1. Verb-form coding in Amazon

\begin{tabular}{lll}
\hline Verb form & Form code & Example \\
\hline Finite form & FIN & glimlacht 'smiles' \\
Past participle & PSP & gegeven 'given' \\
Present participle & PRP & werkend 'working' \\
Infinitive form & INF & doen 'do' \\
te + infinitive & TE & te doen 'to do' \\
Infinitivus pro participio & IPP & wezen 'to be' \\
\hline
\end{tabular}


Table 2. Verb-expectation coding in Amazon

\begin{tabular}{lll}
\hline Verb form & Expectation code & Example \\
\hline Past participle & PSP & hebben 'have' \\
Infinitive form & INF & kunnen 'can' \\
te + infinitive & TE & schijnen 'seem' \\
Optional $t e+$ infinitive & te & zitten 'sit' \\
Infinitivus pro participio & IPP & hebben $/ z i j n$ 'have/be' \\
No expectation & NONE & slapen 'sleep' \\
\hline
\end{tabular}

form with the infinitival marker te, we will distinguish two different te expectations. This distinction will be discussed in section 2.3.

An example of an Amazon parse tree for the cluster zou schijnen te hebben gebeld 'would seem to have called' is shown in II.

(II) An example of an Amazon parse tree

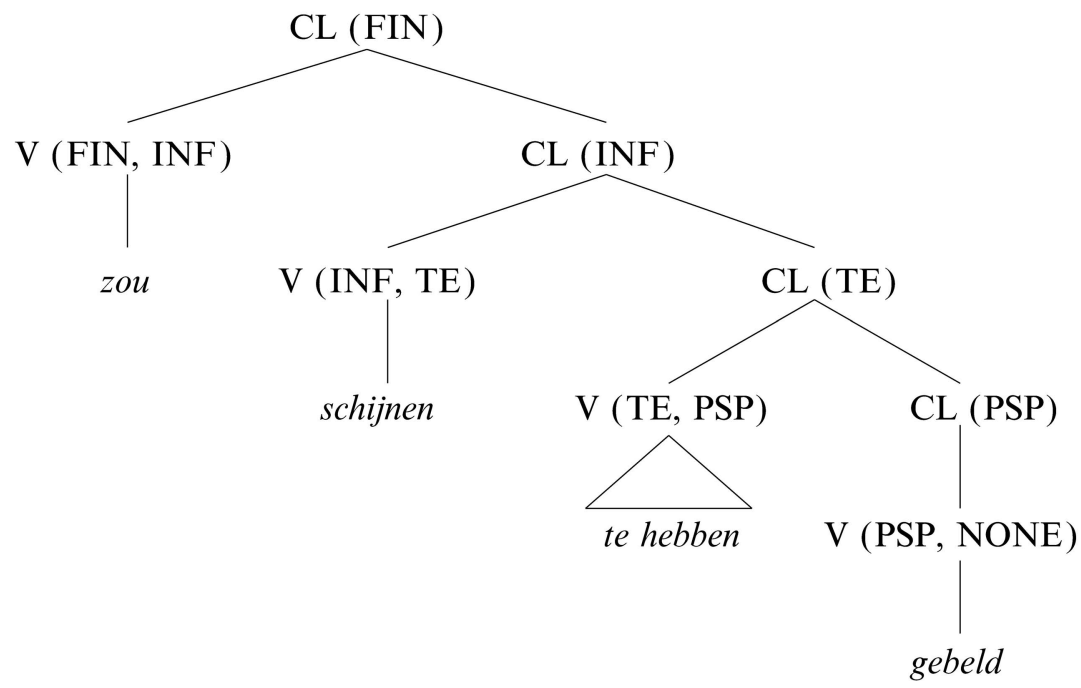

This diagram shows how the verbal expectation threads its way through the verbal cluster. The null expectation generated by the occurrence of the verb gebeld is absolute: there is no way to continue the cluster with another verb:

(13) *... zou schijnen te hebben gebeld kunnen

would seem to have called can

(14) *... zou schijnen te hebben gebeld worden would seem to have called be 


\section{Variations in the verbal cluster}

The expectation algorithm discussed so far describes the general case in Dutch syntax (Van Bakel 1975). However, there are a few deviations from this general scheme in Modern Dutch (Coppen 1987; Oltmans 1994; Van Dreumel and Potjer 1998; Van Dreumel 2000):

(i) Infinitivus pro participio (IPP):

A special infinitive form occurs instead of an expected past participle.

(ii) Unexpected elements:

Certain verbal elements, like the past participle and verb particle, may occur before they are expected.

(iii) Te-drop:

Some verbs introduce an expectation for the infinitival element te, but in specific configurations, it does not occur.

(iv) Infinitive inversion:

Modal verbs introducing an expectation for a bare infinitive may be inverted with this infinitive, provided that the two are clusterfinal.

Van Bakel (1975) incorporated IPP, the unexpected past participle, and the infinitive inversion in his original algorithm and left the te-drop cases as lexical ambiguity. Possible verb particles were recognized, but outside the verbal cluster. In the next sections, we will discuss these four special cases, which are now incorporated into the Amazon grammar.

\subsection{IPP effect}

Dutch, like other Germanic languages (cf. Den Besten 1989) shows the IPP effect in verbal clusters: an expected past participle surfaces as an (apparent) infinitive. The IPP form is intended for verbal forms resembling an infinitive, but occurring in positions where a participle is expected:

(15) Hij heeft niet kunnen slapen

he has not can sleep

'he couldn't sleep'

The perfective auxiliary heeft creates an expectation for a past participle. Consequently, the verb kunnen is expected to occur as a past participle. However, it appears as an infinitive. This is called the IPP effect. 
The decision to distinguish an IPP form from the infinitive is not in accordance with the original Van Bakel analysis, which treated IPP forms and infinitives on a par, probably reasoning from the name infinitivus pro participio suggesting that an expected participle is replaced by an infinitive. However, there is evidence that the IPP form is different from an infinitive:
a. *Jan zal wezen vissen
John will INF-be fish
b. Jan zal zijn vissen
John will INF-be fish
'John will have gone fishing'
a. Jan is wezen vissen
John is IPP-be fish
'John has been fishing'
b. *Jan is zijn vissen
John is INF-be fish

The IPP form of the aspectual auxiliary zijn is not identical to its infinitive. ${ }^{8}$ Moreover, the IPP effect has been shown to be lexically dependent: some verbs are subjected to the effect, others are not. And as expected with idiosyncratic features, there is variation in acceptability for some verbs. Not all Dutch speakers accept the grammaticality of the following sentences:

(18) ?ik heb je nog menen te bellen

I have you MOD mean to call

'I meant to call you'

(19) ?het heeft dreigen te stormen/regenen

it has threatened to storm/rain

'it threatened to storm/rain'

This behavior indicates that the ability to appear in the infinitive form when a past participle is expected is a lexical feature that can very well be considered as a form feature. Therefore we will continue to distinguish the IPP form from the infinitive form.

The IPP effect is restricted to verbs that themselves introduce the expectation of an infinitive (with or without te):

(20) a. ... heeft $[\mathrm{v}(\mathrm{IPP})$ kunnen/willen $]$ opbellen

has $\left[\mathrm{v}_{(\mathrm{IPP})}\right.$ can/want $] \quad$ PRT + call

b. ... heeft $\left[\mathrm{v}_{(\mathrm{IPP})}\right.$ durven/proberen] te bellen

has $\left[\mathrm{v}_{(\mathrm{IPP})}\right.$ dare/try] to call

c. $\quad \ldots$ is $\left[\mathrm{v}_{(\mathrm{IPP})}\right.$ wezen/gaan/komen/blijven] vissen

is $\left[\mathrm{v}_{(\mathrm{IPP})} \mathrm{be} / \mathrm{go} / \mathrm{come} / \mathrm{stay}\right] \quad$ fish 
(21)
a. *... heeft [v(IPP) opbellen/vissen]
has [v(IPP) PRT + call/fish]
b. $* \ldots$ is [ $\mathrm{v(IPP)}$ Worden] opgebeld
is [ $\mathrm{v}_{(\mathrm{IPP})}$ PASS-be] called

Moreover, the IPP effect is restricted to past participles that are expected by the perfective auxiliaries hebben 'have' and zijn PERF-'be'. Although the passive auxiliary worden PASS-'be' also expects a past participle, the following verb can never occur in the IPP form:

a. *... wordt kunnen ophellen

PASS-is can call

b. *... wordt proberen op te bellen

PASS-is try PRT to call

The reason for this may coincide with the first restriction: verbs with a verbal expectation cannot be passivized at all. This holds for all auxiliaries, but also for verbs like proberen 'try'. Although proberen can be passivized, this automatically closes the verbal cluster:
a. Ik wil met iedereen rekening proberen te houden
I want for everyone considering try to show
'I want to show consideration for everyone'
b. Er zal worden geprobeerd met iedereen rekening there will PASS-be tried for everyone consideration te houden
to show
c. Er zal met iedereen worden geprobeerd rekening there will for everyone PASS-be tried consideration te houden
to show
d. *Er zal met iedereen rekening worden geprobeerd there will for everyone consideration PASS-be tried te houden to show

These examples show that the passive past participle geprobeerd cannot form a verbal cluster with the following verb te houden. Arguments to the latter have to intervene between the two verbs and cannot occur in the matrix clause. This indicates that any material following passive geprobeerd is in fact a nontransparent infinitival clause, out of which no scrambling is possible.

In addition to these structural restrictions it can be remarked that only a limited number of verbs may take the IPP form: these are listed in Table 3. ${ }^{9}$

In the Amazon grammar, verbs are lexically marked with two affix 
Table 3. Verbs that can occur in the IPP form

\begin{tabular}{ll}
\hline Type & Example \\
\hline Modal verbs & $\begin{array}{l}\text { kunnen, moeten, mogen, willen, zullen } \\
\text { blijven, gaan, komen; liggen, staan, zitten, lopen }\end{array}$ \\
Aspectual & $\begin{array}{l}\text { doen, helpen, horen, laten, leren, ruiken, vinden, voelen, zien } \\
\text { beginnen, (be) hoeven, behoren, believen, beweren, denken, dreigen, } \\
\text { Several control verbs } \\
\text { durven, hopen, menen, plegen, proberen, trachten, vermogen, } \\
\text { weigeren, weten }\end{array}$ \\
\hline
\end{tabular}

positions, the first indicating the verbal form, and the second indicating the expectation. Both of these affixes may include the code IPP.

In Table 4 some examples are given. Note that the IPP expectation is restricted to the auxiliaries hebben and zijn; the verb worden only expects a past participle (PSP). Since the code IPP occurs both as a form code and as an expectation code, two instances of our general rule scheme (10) are spelled out as follows:

$$
\mathrm{CL}\left(\text { form }_{1}\right) \text { : V (form } 1 \text {, IPP) , CL (IPP) . }
$$

$$
\text { CL (IPP) : V (IPP, }\left[\mathrm{INF}|\mathrm{TE}| \mathrm{te}_{1}\right) \quad, \quad \mathrm{CL}\left(\left[\mathrm{INF}|\mathrm{TE}| \mathrm{te}_{1}\right)\right. \text {. }
$$

Rule (25) accounts for the restriction that a verb in the IPP form necessarily introduces another expectation. ${ }^{10}$ This prevents, for example, the IPP form of proberen from occurring with its null expectation.

In (III) an example of an Amazon parse tree for an IPP construction is given.

(III) An example of a parse tree with IPP

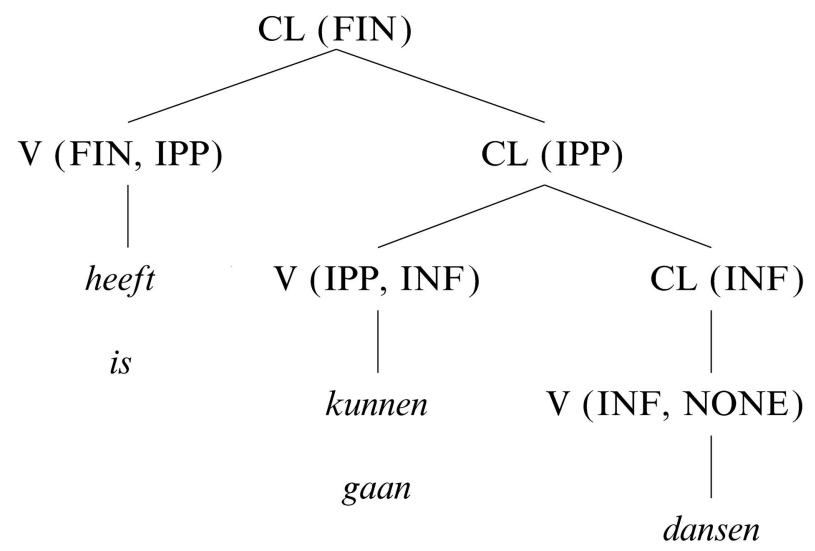

fietsen 
Table 4. Lexical entries for some verbs

\begin{tabular}{lll}
\hline Verb & Form code & Expectation code \\
\hline $\begin{array}{l}\text { hebben } / \text { zijn } \\
\text { worden }\end{array}$ & FIN | INF & PSP | IPP | INF | TE | NONE \\
kunnen & FIN | INF & PSP | NONE \\
$\begin{array}{l}\text { proberen } \\
\text { durven }\end{array}$ & FIN | INF | IPP & INF | NONE \\
\hline
\end{tabular}

\subsection{Unexpected elements}

A second deviation from the general expectation scheme in (10) is that certain elements within the verbal cluster may occur before they are expected. This holds for past participles and verb particles. In general, these can appear anywhere in the verbal cluster: ${ }^{11}$

$$
\begin{aligned}
& \text { a. ik zou wel op tijd }<\text { gebeld }>\text { hebben }<\text { gebeld }> \\
& \text { I would MOD on time }<\text { called }>\text { have }<\text { called }> \\
& \text { willen }<\text { gebeld }>\text { zijn }<\text { gebeld }> \\
& \text { want }<\text { called }>\text { PASS-be }<\text { called }> \\
& \text { 'I would have wanted to have been called in time' } \\
& \text { b. ik zou wel op tijd <op }>\text { hebben }<\text { op }>\text { willen } \\
& \text { I would MOD on time }<\text { up }>\text { have < up }>\text { want } \\
& <\text { op }>\text { kunnen }<\text { op }>\text { staan } \\
& <\text { up }>\text { can < < }>\text { stand } \\
& \text { 'I would have wanted to be able to get up in time' }
\end{aligned}
$$

The unexpected elements in fact create their own expectation. An unexpected past participle at the beginning of a verbal cluster, for example, introduces the expectation of a perfective or passive auxiliary. The verb particle and the past participle may both be considered as nonverbal (or more precisely: LESS VERBAL) elements originating in the same position. We will discuss the unexpected past participle and verb particle, and the combination of both, in separate sections.

2.2.1. Unexpected past participle. The distribution of the past participle as an unexpected element in Modern Dutch is subject to some variation. In small verbal clusters it is relatively easy to have the unexpected past participle in all positions. As the clusters get longer, the peripheral (i.e. cluster-initial or cluster-final) positions are the preferred ones. Of these, the cluster-final position is the canonical position: 
(27) a. ... omdat ik het niet aan hem [ $\mathrm{CL}_{\mathrm{L}}$ zou hebben gegeven] because I it not to him [cL would have given]

b. ... omdat ik het niet aan hem [ ${ }_{\mathrm{CL}}$ zou gegeven hebben] because I it not to him [cL would given have]

c. ... omdat ik het niet aan hem [CL gegeven zou hebben] because I it not to him [cL given would have]

(28) a. ... omdat hij mij schijnt te moeten hebben gebeld because he me seems to must have called

b. $\quad$... omdat hij mij gebeld schijnt te moeten hebben because he me called seems to must have

c. ??... omdat hij mij schijnt te moeten gebeld hebben because he me seems to must called have

d. ?... omdat hij mij schijnt gebeld te moeten hebben because he me seems called to must have

As noted above, the unexpected elements belong to the verb closing the verbal cluster. If the expectation generated by the unexpected element is met, the cluster can be closed. Verbs with their own expectation cannot give rise to unexpected elements. Consider the following examples: ${ }^{12}$
a. ?Hij zou met niemand rekening hebben geprobeerd he would for no-one consideration have tried te houden to show
'Apparently he did not show consideration for anyone'
b. *?Hij zou met niemand rekening geprobeerd hebben he would for no-one consideration tried have te houden to show

In these examples, the expecting verb proberen 'try' occurs in the pastparticiple form. However, it forms a verbal cluster with the next verb te houden 'to hold', since arguments to the latter (met niemand rekening) are placed before the verbal cluster (possibly by scrambling into the matrix clause). This may be only marginally possible. Using the past participle as an unexpected element is clearly worse.

In transformational analyses, the unexpected past participle is considered a climbing element, that moves from its canonical cluster-final position in a stepwise fashion via head-to-head movement to the very beginning of the verbal cluster, leaving a trace at intermediate positions. This analysis is mimicked in the current Amazon grammar by the introduction of a second affix position for the unexpected expectation on the verbal cluster: 
(30) CL (form, unexpected expectation)

Here, the unexpected expectation can take two forms: NONE or PSP. The following rules rewrite the unexpected construction with past participle:

(31) CL (form 1, NONE) :

$$
\begin{aligned}
& \mathrm{V} \text { (PSP, NONE) , CL (form } 1, \text { PSP) . } \\
& \text { CL (form } 1, \text { PSP) : V (form } 1, \text { PSP) . } \\
& \text { CL (form } 1, \text { PSP) : } \\
& \mathrm{V}\left(\text { form }_{1}, \text { expectation }_{2}\right) \text {, CL (expectation } 2, \text { PSP) . }
\end{aligned}
$$

The first rule introduces the unexpected past-participle expectation (PSP). A verb of some form is expected, ${ }^{13}$ and a past participle is encountered. This maintains the expectation of the original form but introduces PSP as an unexpected expectation on the next CL. The second rule states that this CL is satisfied if a verb is encountered of the form that was originally expected, but the verb itself is expecting PSP. The third rule maintains the unexpected expectation. This is the case if the unexpected expectation PSP is active and a verb is encountered of the form that was originally expected, but with some expectation other than PSP itself. In this case, not all expectations are satisfied and the verbal cluster cannot be closed. In (IV), an example of an Amazon parse tree for an unexpected past participle construction is given.

(IV) An example of an unexpected PSP construction

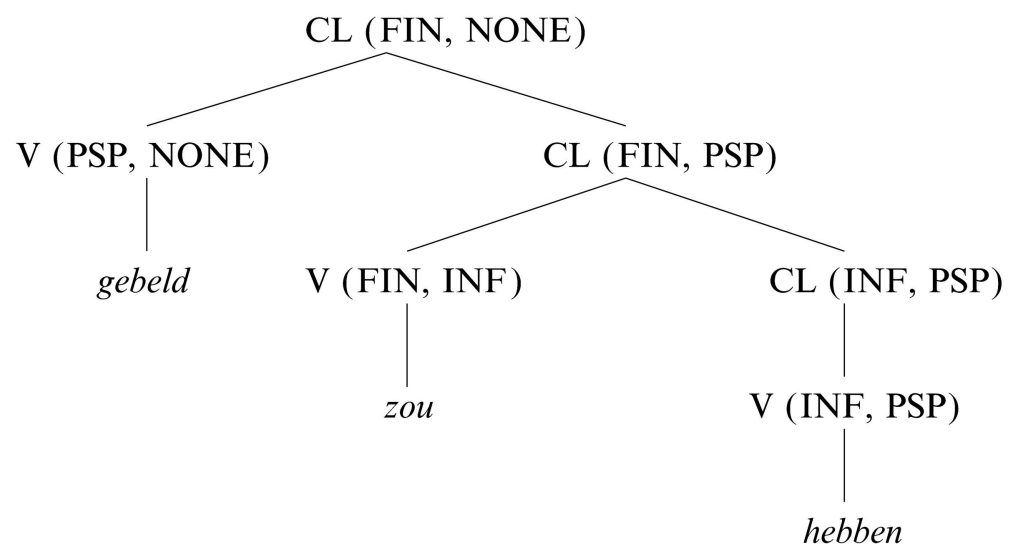

2.2.2. Unexpected verb particles. A second element that can occur unexpectedly is the verb particle. To be more specific, a verb particle that is separable from its verb can occur in exactly the same positions in the verbal cluster as the past participle: 
(34) a. ... dat hij haar zou hebben willen [op + bellen] that he her would have IPP-want [PRT + call]

b. ... dat hij haar op zou hebben willen [bellen] that he her PRT would have IPP-want [call]

c. ?... dat hij haar zou hebben $o p$ willen [bellen] that he her would have PRT IPP-want [call]

d. ?... dat hij haar zou op hebben willen [bellen] that he her would PRT have IPP-want [call]

In the Amazon grammar, the unexpected verb particles are treated on a par with the unexpected past participle, namely in the affix position for unexpected expectation.

$$
\begin{aligned}
& \text { CL }\left(\text { form }_{1}, \mathrm{NONE}\right): \text { Prt }\left(\operatorname{prt}_{2}\right), \text { CL }\left(\text { form }_{1}, \operatorname{prt}_{2}\right) \\
& \text { CL }\left(\text { form }_{1}, \operatorname{prt}_{2}\right): \text { V }\left(\text { form }_{1}, \operatorname{prt}_{2}\right) \text {. } \\
& \text { CL }\left(\text { form }_{1}, \operatorname{prt}_{2}\right): \\
& \text { V }\left(\text { form }_{1}, \text { expectation }_{3}\right) \quad, \quad \text { CL }\left(\text { expectation }_{3}, \operatorname{prt}_{2}\right) .
\end{aligned}
$$

Unexpected verb-particle expectation works in exactly the same way as the unexpected past-participle expectation; the only difference is that all verbs with separable verb particles have to be marked in the lexicon as satisfying a specific verb-particle expectation. In Table 5, some examples are given.

It may seem impossible to list all verb particles in the lexicon, but in fact, the list of possible verb particles in Dutch is relatively short (approximately 210 elements).

It may also seem inappropriate to try to link verb particles with their verbs if they occur discontinuously, because the relation between the two can be considered as a SUBCATEGORIZATION relation. Since Amazon is a surface parser in nature, it would seem wrong to treat subcategorization in Amazon. However, we see the relation between verb and particle as a MORPHOLOGICAL relation. The unexpected verb-particle construction is not an instance of a simple verb selecting a particle, but rather an example of a complex verb that occurs discontinuously. Reconstructing words does belong to the aims of a surface parser and should therefore be treated in Amazon (Van Dreumel 2000).

Table 5. Lexical entries for verbs satisfying verb-particle expectation

\begin{tabular}{lll}
\hline Verb & Form & Particle \\
\hline bellen & FIN $\mid$ INF & NONE $\mid$ AAN $\mid$ AF $\mid$ DOOR | IN | OP | TERUG \\
lopen & FIN | INF & NONE $\mid$ AAN $\mid$ AF $\mid$ DOOR | IN | MEE $\mid$ OM $\mid$ OP $\mid$ OVER $\mid$ NA $\mid$ TERUG \\
\hline
\end{tabular}


In (V) an example of an Amazon parse tree for an unexpected verbparticle construction is given.

(V) An example of a cluster with an unexpected verb particle

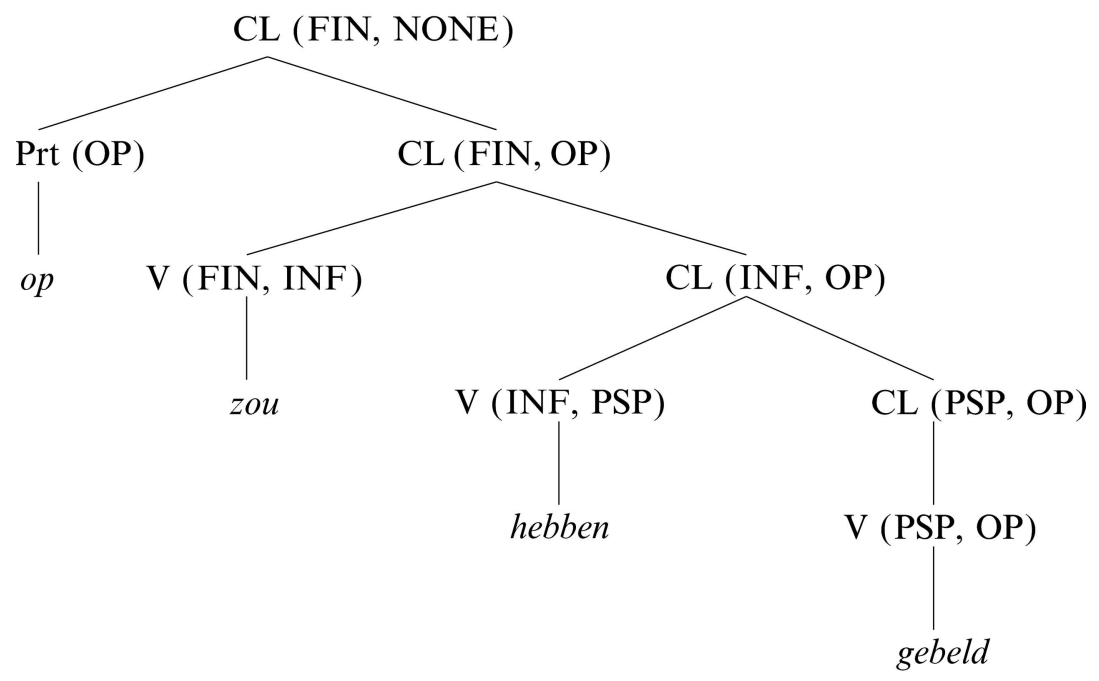

2.2.3. Combination of unexpected elements. Treating the unexpected past participle and verb particle on a par within the same affix position would seem to predict that the two cannot appear within the same verbal cluster. However, this prediction turns out to be false:

?... omdat Jan haar op zou gebeld hebben because John her PRT would called have '... because John apparently called her'

In this example, both the particle $o p$ and the past participle gebeld are unexpected. However, a closer examination of this cluster shows that the verb-particle expectation and the past-participle expectation cannot occur SIMULTANEOUSLY in the same position. It rather seems that the unexpected verb-particle expectation is satisfied by the verb gebeld and replaced by an unexpected past-participle expectation. This replacement can be accounted for in the following rule:

$$
\text { CL (form } \left.\left.1, \mathrm{prt}_{2}\right) \text { : V (PSP, } \mathrm{prt}_{2}\right) \text {, CL (form } 1, \text { PSP) . }
$$

This rule states that in the case of an active unexpected particle expectation and some form expectation (other than PSP), a past participle may satisfy the particle expectation and replace it by an unexpected PSP expectation, maintaining the original form expectation. 
This treatment correctly accounts for the fact that an unexpected past participle can never occur BEFORE an unexpected verb particle:
a. *... omdat Jan haar gebeld op zou hebben because John her called PRT would have
b. *... omdat Jan haar gebeld zou op hebben because John her called would PRT have
c. *... omdat Jan haar gebeld zou hebben op because John her called would have PRT

Apparently, an unexpected verb-particle expectation can never replace an unexpected past-participle expectation. The reason for this may be that both relate to the verb closing the verbal cluster, and of the two, the past participle is in fact the closing verb itself. If we meet the expectation of the closing verb itself, the cluster is immediately closed. In (VI) an example of the replacement construction is given.

(VI) Replacement of unexpected expectation

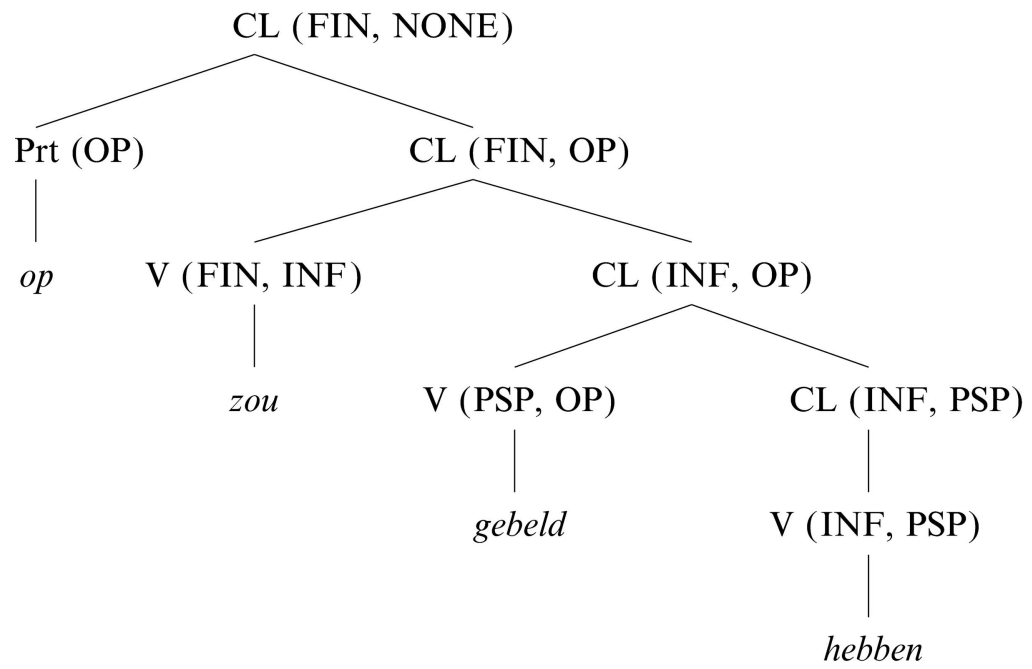

\subsection{Te-drop}

Some verbs introduce the expectation of an infinitive verb form with the infinitival marker te, but they allow the marker to be absent in some configurations. This generally holds for a group of aspectual locational auxiliaries (lopen 'walk', zitten 'sit', liggen 'lie', staan 'stand', hangen 'hang'), but also for some other verbs (durven 'dare', hoeven 'need'). If 
these verbs occur in cluster-initial position, or in verb-second position, they introduce a normal expectation of the infinitival marker $t e:^{14}$
a. Hij zit altijd *(te) tekenen
he sits always to draw
'he is always drawing'
b. ... omdat hij altijd zit *(te) tekenen
because he always sits to draw

However, in other configurations, the infinitival marker te can (and sometimes MUST) be dropped:
a. Hij moet altijd zitten ?(te) tekenen
he must always sit
to draw
'He always must draw'
b. Hij heeft de hele tijd zitten (te) tekenen
he has the whole time sit to draw
c. Ik verbied je om de hele tijd te zitten $(*$ te) tekenen
I forbid you COMP the whole time to sit to draw
d. Ik verbied je om te gaan zitten (*?te) tekenen
I forbid you COMP to to sit to draw

In the first example, the verb expecting te is cluster-initial but is itself expected by the finite verb. In the second example, the verb expecting te is in the IPP form. The third and fourth example show an infinitival clause with complementizer om, which itself expects $t e$. in these contexts there appears to be strong resistance against the infinitival marker. ${ }^{15}$

However, if we compare the examples in (42) with those in (43), in which the verb zitten has been replaced by proberen, which also selects the infinitival marker $t e$, we find that it is impossible to drop te, disregarding the context in which the verb occurs.
a. Hij moet altijd proberen *(te) tekenen
he must always try to draw
'He always has to try to draw'
b. Hij heeft de hele tijd proberen *(te) tekenen he has the whole time sit to draw
c. Ik verbied je om de hele tijd te proberen*(te) I forbid you COMP the whole time to try to tekenen draw
d. Ik verbied je om te gaan proberen *(te) tekenen I forbid you COMP to go try to draw

It is clear that the possibility of dropping te is not only structurally 
induced, but also lexically dependent. Only a small selection of verbs with te expectation is sensitive to the te-drop contexts. ${ }^{16}$

To account for the te-drop phenomenon in the Amazon grammar, two factors have to be coded:

- the lexical te expectation, which can be "weak" (optional) or "strong" (obligatory);

- the structural configuration, which can be "te-resistant," "te-neutral," or "te-prone."

A strong te expectation requires te even in te-resistant configurations, a weak te expectation does not get te in $t e$-resistant contexts and may have te in te-neutral contexts.

In the Amazon lexicon, the lexical dependency is marked on the verb. A distinction is made between an expectation TE and te, for "strong $t e$ " and "weak te," respectively. The expectation of a finite verb creates a te-prone context, and clusters with an earlier te become te-resistant.

We chose to add a third affix position to the CL node, indicating te-resistancy, with affix values +TE, 0TE and -TE. The following grammar rules illustrate the formalization:

(44) CL (FIN, NONE, 0TE) :

V (FIN, expectation 1$)$, CL (expectation 1, NONE, +TE) .

(45) $\mathrm{CL}\left([\mathrm{INF} \mid \mathrm{PSP}]_{1}, \mathrm{NONE},[-\mathrm{TE} \mid 0 \mathrm{TE}]_{3}\right)$ :

$\mathrm{V}\left([\mathrm{INF} \mid \mathrm{PSP}]_{1}\right.$, expectation $\left.{ }_{2}\right)$,

CL (expectation ${ }_{2}$, NONE, $\left.[-\mathrm{TE} \mid 0 \mathrm{TE}]_{3}\right)$.

(46) $\mathrm{CL}\left([\mathrm{INF} \mid \mathrm{PSP}]_{1}, \mathrm{NONE},+\mathrm{TE}\right)$ :

$\mathrm{V}\left([\mathrm{INF} \mid \mathrm{PSP}]_{1}\right.$, expectation $\left.{ }_{2}\right)$,

CL (expectation, , NONE, OTE) .

(47) CL (TE, NONE, +TE $|0 \mathrm{TE}|-\mathrm{TE})$ :

$\mathrm{P}(\mathrm{TE}), \mathrm{V}\left(\mathrm{INF}\right.$, expectation $\left._{2}\right)$,

CL (expectation, , NONE, -TE) .

(48) CL (te, NONE, $\left.[0 \mathrm{TE} \mid-\mathrm{TE}]_{1}\right)$ :

$\mathrm{V}\left(\mathrm{INF}\right.$, expectation $\left._{2}\right)$,

CL (expectation, , NONE, $\left.[0 \mathrm{TE} \mid-\mathrm{TE}]_{1}\right)$.

CL (te, NONE, [0TE $\mid+$ TE]) :

$\mathrm{P}(\mathrm{TE}), \mathrm{V}\left(\mathrm{INF}\right.$, expectation $\left._{2}\right)$,

CL (expectation, , NONE, -TE) .

The idea behind these rules is simple: verbal clusters start with neutral te resistancy. Only finite verbs may create "te proneness" (formalized by $+\mathrm{TE}$ ). As long as te is not expected (neither weak nor strong), te proneness is neutralized and te resistancy pertains. Strong te expectation requires te and generates a te-resistant context. Weak te expectation does 
not allow te in te-resistant contexts, requires te in te-prone contexts, and may or may not have te in neutral contexts; see (VII).

(VII) Analysis of te-drop configuration

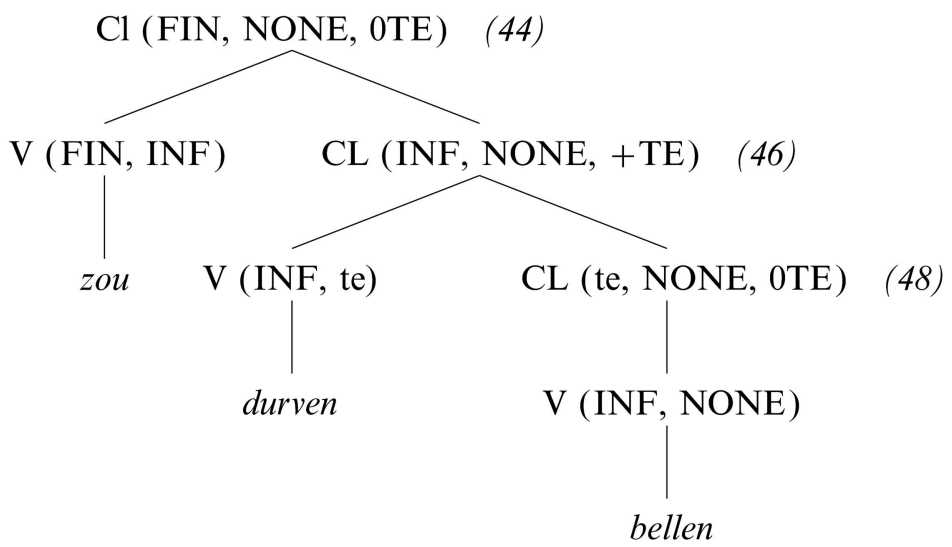

In any case, if te is encountered, and allowed, a te-resistant context is generated.

The formalization discussed above captures the distributional facts of te drop rather well. However, there seems to be some variation in judgment for certain verbs:

(50) a. zou durven (te) bellen would dare (to) call

b. schijnt te durven (?te) bellen seems to dare (?to) call

c. schijnt te hebben durven (*?te) bellen seems to have dare (*?to) call

Apparently, durven has a weak te expectation. The formalization so far correctly predicts that te-drop is possible in all of these cases. In (50a), a te-neutral context is generated by the infinitive form of durven. In (50b) and (50c), however, the generation of $t e$, as a result of the strong te expectation of schijnen, creates a te-resistant context, in which te, according to the algorithm, has to be dropped. However, te seems to be marginally possible in these cases, although it is certainly worse in $(50 \mathrm{c})$, where durven is also the IPP form.

In spite of these examples, we feel that the formalization is basically correct. We realize that the current Amazon parser will not analyse (50c) if te is included, while it will consider (50b) to be an instance of an extraposed infinitive complement te bellen. The fact that this is a less 
felicitous analysis is left to be explained in other grammatical modules subsequent to the Amazon parser.

\subsection{Infinitive inversion}

The final exception to the general rule in (10) is a very restricted inversion of the verb and its infinitival complement:
a. ... omdat je me niet zult verrassen because you me not will surprise
'... because you will not surprise me'
b. ... omdat je me niet verrassen zult because you me not surprise will

The example in (51b) deviates from the general scheme: the infinitive verb form verrassen is expected by the auxiliary zult, but it precedes the auxiliary. However, it does not seem adequate to consider the infinitive as an unexpected element, since the inversion seems to be restricted to verb clusters with two elements: ${ }^{17}$

(52) a. ... omdat je me niet zult kunnen verrassen because you me not will can surprise 'because you will not be able to surprise me'

b. ??... omdat je me niet verrassen kunnen zult because you me not surprise can will

c. *?... omdat je me niet zult verrassen kunnen because you me not will surprise can

d. *?... omdat je me niet verrassen zult kunnen because you me not surprise will can

In addition, the inversion of an infinitive and its selecting verb seems to be restricted to the verbs mentioned in Table 6 .

Moreover, the variation can only occur in the verbal cluster of a subordinate clause. This, however, is the result of the verb-second

Table 6. Verbs that can trigger infinitive inversion

\begin{tabular}{lll}
\hline Type & Example & Gloss \\
\hline Modal verbs & zullen, kunnen, moeten, mogen, willen & 'will, can, must, may, want' \\
Aspectual verbs & gaan, komen & 'go, come' \\
Causative verbs & laten, doen & 'let/make, do' \\
Perception verbs & zien, horen & 'see, hear' \\
\hline
\end{tabular}


phenomenon in Dutch, which moves the finite verb out of the cluster. A cluster of two verbs in a main clause can only be generated from a basic three-verbal cluster. Since the inversion is virtually impossible in a cluster with three verbs, it cannot occur in the surface form of main clauses either.

The grammar rules for the inverse order are as follows:

(53) CL (FIN, NONE, 0TE) :

CL (INF, INF INV, 0TE) , V (FIN, INF) .

CL (INF, INF INV, OTE) : V (INF, NONE) .

\section{Other restrictions to the verbal cluster}

In section 2, we presented the basic frame for the Dutch verbal cluster, and we discussed four structural deviations from this frame. In addition, there are many more restrictions to the distribution of verbs in the cluster (Coppen et al. 1991), some of which are idiosyncratic, some semantic, and others collocational. In this section, we will discuss a few of these additional restrictions and their relation to the performance of the Amazon parser. In general, the parser will OVERGENERATE and so accept these cases and leave them for treatment in subsequent modules.

A first restriction that can be observed is that there can be only one aspectual verb of a particular subtype in the same cluster:

$$
\begin{aligned}
& \text { *... omdat hij weer ligt te zitten klieren } \\
& \text { because he again lies to sit nag } \\
& \text { '... because he lies and sits and nags again' } \\
& \text { *?.. omdat hij weer komt zitten (te) niksen } \\
& \text { because he again comes sit to do-nothing } \\
& \text { '... because he again comes to sit and do nothing' }
\end{aligned}
$$

Although this restriction most certainly has a semantic origin, it could also be accounted for in the surface-structure description of the verbal cluster. A generalization will be missed then, however, since the restriction holds in other constructions as well:

$$
\begin{aligned}
& \text { *... omdat hij weer ligt te proberen om flink te zitten } \\
& \text { because he again lies to try COMP heavily to sit } \\
& \text { klieren } \\
& \text { nag } \\
& \text { '... because he again lies and tries to sit and nag heavily' }
\end{aligned}
$$

In this example, both aspectual verbs belong to different clauses. Yet, this sentence is as ungrammatical as the one-clause example. A semantic constraint captures the generalization more adequately. 
A second restriction that seems structural is that the aspectual verb must be followed immediately by the main verb:

*Hij zal wel weer zitten te kunnen zingen he will MOD again sit to can sing

*De kerstboom staat te worden bekeken the Christmas tree stands to become watched

(60) *Je moet ze niet steeds staan te laten passeren you must them not always stand to let pass

Amazon will accept all of these examples as acceptable verbal clusters. This is clearly wrong. However, we may again question the syntactic nature of this restriction. In the first place, constructions with the aspectual verbs komen or gaan followed by the the causative verb laten are (sometimes marginally) acceptable:

(61) ??Hij wil zijn aapje komen laten dansen he wants his ape come let dance 'He wants to come and let his ape dance' (62) Wanneer kom je me je werk laten zien? when come you me your work let see? 'When will you come and show me your work?'

Second, aspectual verbs show restrictions in the choice of their main verb:

(63) Ik zit net de zonsverduistering te [*zien/bekijken]

I sit just the solar eclipse to [*see/watch]

(64) Jan staat weer eens boos te [?zijn/wezen/worden/*blijven] John stands again once angry to [be/be/become/stay]

(65) Marie loopt veel plezier te [?hebben/*krijgen] Mary walks much fun to [have/get]

Whatever the nature of these restrictions is, we feel that they should be accounted for semantically and not structurally. The fact that no auxiliary can follow the aspectual verb may very well originate in the auxiliary semantics. Therefore, we let Amazon overgenerate and accept these cases, leaving it to more subtle semantic devices to rule them out. No real harm is done with this provisory solution, since no grammatical sentences are falsely rejected.

A third restriction is that perception verbs and causative verbs cannot be followed by passive, modal, or temporal auxiliaries, and only marginally by aspectual auxiliaries:

(66) a. *We zullen je laten worden gebeld we will you let PASS-be called 
b. *?Je moet me laten kunnen doen wat ik wil you must me let can do what I want

c. *Hij laat mij zijn opdracht op tijd hebben uitgevoerd he lets me his appointment on time have executed

a. *Ze hebben hun disks zien worden vernietigd they have their disks see PASS-be destroyed

b. *?Hij moest me eens zien kunnen schaatsen he must me sometimes see can skate

c. *Hij ziet mij zijn opdracht op tijd hebben uitgevoerd he sees me his appointment on time have executed

There may very well be a syntactic source for this phenomenon. Both perception verbs and causative verbs select infinitival complements without te, marking the subjects of the latter with the accusative case. This has long been known as the accusativus cum infinitivo construction. In generative literature, it is derived through some mechanism of exceptional case marking or a process of raising to object (RTO) that moves the subject of the subordinate clause to an argument position of the matrix verb. Within the framework of one of the latter solutions, an obvious explanation for the ungrammaticality of the above examples would be that the case-marking process or the raising of the subject is blocked by intervening auxiliaries. Within the movement approach, some version of a minimality constraint is probably sufficient.

Be this as it may, to treat this phenomenon would have to involve marking causative auxiliaries and perception verbs with some special property, which in fact would be equivalent to the exceptional casemarking property or the RTO property. Since this is subcategorization (Van Dreumel 1996) in nature, it does not seem appropriate to include it in a surface parser. Therefore, we chose to let the Amazon parser overgenerate and treat all subcategorization restrictions in the subsequent module Casus. Since, again, no grammatical sentences are falsely rejected and no inappropriate analyses are generated, no harm is done.

In conclusion, the additional restrictions to the verbal cluster are not included in the Amazon grammar for various reasons.

\section{The contribution of verbal-cluster parsing to sentence parsing}

In this section, we will evaluate the contribution of the current description of the verbal cluster to the parsing of Dutch sentences in general. From this discussion it will become clear that a correct grammatical description of the verbal cluster does not solve all parsing problems, but that it contributes significantly to the success of the parser. 
Since every clause is defined by the existence of a verbal cluster (gapping clauses excluded), a correct identification of each verbal cluster will provide the basis for the determination of the clausal structure of the sentence to be parsed. The precise boundaries of the clauses will in many cases not be identifiable by a surface parser, since the boundary may depend on semantic information or subcategorization. In particular, phrases directly following the verbal cluster of an embedded clause may be either extraposed or part of the matrix clause:

(68) ik wil het boek dat ik kocht in de winkel lezen

I want the book that I bought in the shop read

'I want to read the book that I bought in the shop'

We will call the closing boundary of the embedded relative clause a transparent boundary. Elements adjacent to a transparent boundary may be interpreted in either clause. Although Amazon will correctiy identify the two verbal clusters kocht and wil lezen in sentence (68) with verbsecond, there is no way to decide where the PP in de winkel has to be attached. However, Amazon takes a very practical view here: it will only generate the highest attachment for the PP, leaving the decision whether or not to lower the PP to the next module. So, although this source of ambiguity is not solved, it is neutralized by underspecifying the parse tree with respect to the PP attachment.

The main contribution that the verbal-cluster subgrammar makes to the parsing process lies in the unraveling of strings of verbs into one or more coherent groups. We will first give an example of a complex cluster:

$$
\begin{aligned}
& \text {... zou hebben willen zien durven blijven staan kijken } \\
& \text { would have want see dare stay stand look } \\
& \text { 'would have wanted to see [someone] dare to stay stand and look' }
\end{aligned}
$$

Amazon correctly describes this enormous verbal cluster in the following fashion: zou expects an infinitive, hebben satisfies this and expects (among others) a past participle. Being an IPP form, willen satisfies this and in turn expects an infinitive. Zien meets this requirement and creates another infinitive expectation, which is satisfied by durven. Now durven has a weak te expectation and the context is te-neutral, so either te or a bare infinitive is accepted. Blijven is a bare infinitive expecting yet another bare infinitive. Thus, staan is accepted, resulting in yet another weak te expectation. Since the te resistance has not changed, both te and a bare infinitive are acceptable. Finally, kijken, being a bare infinitive with no expectation of its own, closes the cluster.

Next, we compare the last example with this one: 
(70) ... zou hebben willen beloven te durven blijven staan kijken would have want promise to dare stay stand look 'would have wanted to promise to dare to stay stand and look'

Since beloven is marked as a verb without expectations (it cannot form a coherent group with the next verb), Amazon will correctly close the cluster at that point and start a new clause with an initial (strong) te expectation. At the clause boundary, many other elements are possible, including complements and adverbials to the next verb. So, Amazon will consider any verbs subsequent to beloven as belonging to a separate clause. However, it seems possible to apply scrambling to this clause:

(71) ?... omdat ik dat boek heb beloofd te lezen because I that book have promised to read

'... because I promised to read that book'

Scrambling suggests that heb beloofd te lezen is a verbal group. Yet, this suggestion is false, since adverbials may intervene between beloofd and te lezen: ${ }^{18}$

(72) ?... omdat ik dat boek heb beloofd morgen te lezen because I that book have promised tomorrow to read '... because I promised to read that book tomorrow'

Moreover, no unexpected elements can enter into the cluster heb beloofd, indicating that there are in fact two clusters:

(73) ?... omdat ik dat boek heb beloofd mee te nemen

... because I that book have promised along to take

'... because I promised to bring that book along'

(74) *... omdat ik dat boek heb mee beloofd te nemen because I that book have along promised to take

*... omdat ik dat boek mee heb beloofd te nemen because I that book along have promised to take

Obviously, lexical properties of verbs may cause their own ambiguities:

(76) Ik wil proberen te komen

I want try to come

'I want to try to come'

Since proberen either expects (strong) te, or nothing at all, the following verb te komen can be analyzed either as part of the verbal cluster, or as a separate clause. Both analyses can be justified: 
(77) Ik wil je op proberen te bellen

I want you up try to call

'I want to try to call you'

(78) Ik wil je proberen morgen te bellen

I want you try tomorrow to call

'I want to try to call you tomorrow'

*Ik wil je op proberen morgen te bellen
I want you up try tomorrow to call

It is possible either to add an unexpected verb particle before proberen, or to add an adverbial between proberen and te bellen. The fact that these two elements cannot cooccur supports the analysis in which they indicate different structures.

Since both analyses can be corroborated, we are left with an ambiguity for (76). However, since the ambiguity is only structural (it is hard to see any semantic difference), we chose to let Amazon produce only one of the possibilities. To do so, we formalized the strategy that whenever a verbal-cluster analysis is possible, Amazon prefers it. ${ }^{19}$ In other words, Amazon will produce the one-cluster analysis for (76), although the other possibility is recognized but suppressed.

\section{Conclusions}

We tested Amazon on all the verbal-cluster examples given in the leading Dutch traditional grammar (Haeseryn et al. 1997). All of these (more than 300 sentences) were analyzed correctly and unambiguously. From these results, we may conclude that the Amazon grammar is an adequate first step in parsing Dutch sentences. Full parsing, including functional and semantic analysis, has so far never been achieved by any naturallanguage parser, but it is evident that it must be based on a sound and complete description of the structural properties of the language. We claim that the description given in this article and implemented in the Amazon grammar is the most complete description so far. Even if we agree that the ultimate goal of a parser is a more enriched analysis, or that it is the ultimate goal of linguistic theory to provide a deeper explanation of the facts, we must not forget that correctly describing the facts remains a necessary prerequisite to achieving these goals.

Received 28 November 1999

University of Nijmegen

Revised version received

26 October 2001 


\section{Notes}

* We would like to thank the readers Hans Broekhuis, Ingrid van Canegem-Ardijns, Marcel den Dikken, Hans van Halteren, Henk van den Heuvel, Erwin Marsi, Inge de Mönnink, Anneke Neijt, Jasper Potjer, Carla Schelfhout, and Ineke Schuurman for their useful comments and remarks on earlier versions of this article. Correspondence address: Afd. Taal en Spraak, Faculteit der Letteren, Katholieke Universiteit Nijmegen, Postbus 9103, 6500 HD Nijmegen, The Netherlands. E-mail: s.v.dreumel@let.kun.nl; p.a.coppen@let.kun.nl.

1. For an introduction to the Amazon parser, we refer to Van Dreumel and Potjer (1998), Van Dreumel (2000), and Van Bakel (1984), where the use of surface parsing in a larger natural-language processing system is discussed in more detail.

2. Dutch is a verb-second language, which entails that in main clauses, the finite verb is separated from the other verbs; throughout this article, we will often use subordinate clauses as examples to avoid this complication.

3. In section 2, we will discuss some exceptions.

4. One of the subsequent module is Casus. More about the Amazon Casus system can be found in Coppen (1995).

5. In subordinate clauses, the first verbal pole is identified with the complementizer position.

6. Throughout this article, the AGFL grammar formalism (cf. Koster 1991) will be used to exemplify grammar rules. We will use the convention that coindexed affixes indicate identical values.

7. Constructions like hij is stervend(e) 'he is dying' and hij is lopend 'he is walking' are archaic or idiosyncratic.

8. On the other hand, the infinitival form wezen is not restricted to the IPP construction, as can be seen from examples like hij zit mooi te ?zijn/wezen lit. 'he sits handsome to be'.

9. This list is derived from different resources (Den Besten et al. 1988; Haeseryn et al. 1997).

10. The bar sign | in the rule indicates disjunction.

11. The cluster-initial and cluster-final positions are preferred by most native speakers.

12. The verbal clusters with expecting verbs occurring in the past-participle form are accepted in Standard Dutch. However, judgments may vary on individual examples (Haeseryn 1990). The judgments given here are not absolute but should be considered relative. This also holds also for the examples in (23).

13. It can be any form other than a past participle.

14. In subordinate clauses, the plural finite verbs also trigger te drop: omdat ze altijd zitten (te) tekenen. This is probably due to the similarity between infinitive and plural form in the present tense.

15. There is a peculiar variant of the fourth example in colloquial spoken Dutch:
a. *?Ik verbied je om gaan te zitten tekenen I forbid you COMP go to sit draw
b. ?U hoeft niet zelf uw website nog eens gaan te promoten you need not self your website PRT PRTgo to promote 'You don't need to promote your website yourself'

The infinitival te appears at the one position where it is not expected. It almost seems as if the expected marker "lowers" from the cluster-initial position to the place after gaan, where it cannot lower further because after zitten the resistance against it is too 
high. Be this as it may, this behavior is restricted to the aspectual verb gaan (and marginally komen and mogen) and need not be accounted for structurally.

16. There is also some strong regional variation here. It may be tempting to relate the weakness of te expectation to different underlying constructions (e.g. aspectual verbs versus main verbs) but we fail to see the difference, for instance, between constructions with durven and constructions with proberen. For the moment, we will assume plain lexical variation here.

17. Some Dutch speakers also accept the inversion (52b) with three elements. But longer clusters, like verrassen zult hebben kunnen are totally unacceptable.

18. The nonintervention of adverbials was our prime criterion for identifying verbal groups.

19. This is done by employing the penalty facilities of AGFL, with which less felicitous analyses can be suppressed.

\section{References}

Bech, Gunnar (1955). Studien über das deutsche Verbum infinitum. Copenhagen: Munksgaard.

Bennis, Hans (1991). Theoretische aspekten van partikelvooropplaatsing II. Tabu 21(3), 89-95.

- (1992). Long head movement: the position of particles in the verbal cluster in Dutch. In Linguistics in the Netherlands 1992, Reineke Bok-Bennema and Roeland van Hout (eds.), 37-48. Amsterdam: Benjamins.

- (1998). Waar is het werkwoord? Deel IV: ANS en Hans op avontuur. Nederlandse taalkunde 3, 195-207.

Booij, Geert E. (1998). Samenkoppelingen en grammaticalisatie. In Morfologiedagen 1996. Cahiers van het Meertens Instituut, Eric Hoekstra and Caroline Smits (eds.), vol. 10, 6-20. Amsterdam: Meertens Institute.

Bresnan, Joan; Kaplan, Ronald M; Peters, Stanley; and Zaenen, Annie (1983). Cross-serial dependencies in Dutch. Linguistic Inquiry 13(4), 613.

Broekhuis, Hans (1993). Verb projection raising. Spektator 22(1), 28-47.

- (1997). Nogmaals verb projection raising. Tabu 27(1), 1-27.

-; den Besten, Hans; Hoekstra, Kees; and Rutten, Jean (1995). Infinitival complementation in Dutch: on remnant extraposition. Linguistic Review 12, 93-122.

Coppen, Peter-Arno (1987). Het Amazon-algoritme voor werkwoordelijke eindclusters. Gramma 11(3), 153-167.

- (1995). A new version of the Amazon/Casus system. In Proceedings of the Department of Language and Speech, Pieter de Haan and Nelleke Oostdijk (eds.), vol. 18, 85-90. Nijmegen: University of Nijmegen. http://lands.let.kun.nl/TSpublic/dreumel/ amacas.en.html

-; and Klein, Maarten (1992). Het einde van verb raising. In Nieuwe Eskapades in de Neerlandistiek, Maarten Klein (ed.). Groningen: Wolters-Noordhoff.

—; van der Borgt, Rian; van Dreumel, Simon; and Teunissen, Lisanne (1991). Generating syntactic structures. In Proceedings of the Department of Language and Speech, vol. 15, 52-62. Nijmegen: University of Nijmegen.

Den Besten, Hans (1986). Decidability in the syntax of verbs of (not necessarily) WestGermanic languages. Groninger Arbeiten zur germanistischen Linguistik 28, 232-256.

- (1989). Studies in West Germanic syntax. Unpublished Ph.D. dissertation, University of Tilburg. 
-; and Broekhuis, Hans (1989). Woordvolgorde in de werkwoordelijke eindreeks. Glot $12,79-137$.

-; and Broekhuis, Hans (1990). Woordvolgorde in de werkwoordelijke eindreeks. Unpublished manuscript, University of Amsterdam.

-; and Broekhuis, Hans (1992). Verb projection raising in het Nederlands. Spektator 21(2), 21-34.

-; and Edmondson, Joe (1983). The verbal complex in continental West Germanic. In On the Formal Syntax of the Westgermania, Werner Abraham (ed.). Amsterdam: Benjamins.

-; and Rutten, Jean (1989). On verb raising, extraposition, and free word order in Dutch. In Sentential Complementation and the Lexicon, Dany Jaspers, Wim Klooster, Yvan Putseys, and Pieter Seuren (eds.). Dordrecht: Foris.

—; Rutten, Jean; Veenstra, Tonjes; and Veld, Joop (1988). Verb raising, extrapositie en de derde constructie. Unpublished Ms. thesis, University of Amsterdam.

Den Dikken, Marcel (1992). Particles. Unpublished Ph.D. dissertation, University of Leiden.

Evers, Arnold (1975). The transformational cycle in Dutch and German. Unpublished Ph.D. dissertation, University of Utrecht.

Groos, Anneke (1989). Particle-verbs and adjunction. In Linguistics in the Netherlands 1989, Hans Bennis, and Ans van Kemenade (eds.), 51-60. Dordrecht: Foris.

Haegeman, Liliane; and van Riemsdijk, Henk (1986). Verb projection raising, scope, and the typology of rules affecting verbs. Linguistic Inquiry 17, 417-466.

Haeseryn, Walter (1990). Syntactische normen in het Nederlands. Een empirisch onderzoek naar volgordevariatie in de werkwoordelijke eindgroep. Unpublished Ph.D. dissertation, University of Nijmegen.

-; Romijn, Kirsten; Geerts, Guido; de Rooij, Jaap; and van den Toorn, Maarten C. (eds.) (1997). Algemene Nederlandse Spraakkunst (ANS), 2nd ed. Groningen: Martinus Nijhoff.

Hoeksema, Jack (1980). Verbale verstrengeling. Spektator 10, 221-249.

- (1991). Theoretische aspekten van partikelvooropplaatsing. Tabu 21(1), 18-26.

Kathol, Andreas (1996). Order variability in German and Dutch verb clusters. In Computational Linguistics in the Netherlands 1995, Gert Durieux, Walter Daelemans, and Stephen Gillis (eds.), 147-164. Antwerp.

Koster, Cees H. A. (1991). Affix grammars for natural languages. In Attribute Grammars, Applications and Systems. International Summer School SAGA. Prague, Czechoslovakia. Lecture Notes in Computer Science, vol. 545. Berlin: Springer. http://lands.cs.kun.nl/agfl

Koster, Jan (1975). Dutch as an SOV Language. Linguistic Analysis 1, 111-136.

Neeleman, Ad (1994). Complex predicates. Unpublished Ph.D. dissertation, University of Utrecht.

Oltmans, Erik (1994). Amazon in AGFL: een contextvrije herschrijfgrammatica voor de structurele module van het AMAZON/CASUS-systeem, beschreven in het AGFLformalisme. Unpublished Ms. thesis, University of Nijmegen.

Richter, Michael (2000). Verbkonstruktionen im Deutschen. Eine transformationelle Analyse syntaktischer Erscheinungen innerhalb des deutschen Verbsystems im Rahmen der semantischen Syntax. Unpublished Ph.D. dissertation, University of Nijmegen.

Rijpma, E.; and Schuringa, F. (1968). Nederlandse Spraakkunst, Jan van Bakel (ed.). Groningen: Wolters-Noordhoff.

Rutten, Jean (1991). Infinitival complements and auxiliaries. Unpublished Ph.D. dissertation, University of Amsterdam.

Seuren, Pieter (1973). Predicate Raising and Dative in French and Sundry Languages. Trier: Linguistic Agency University of Trier.

-(1996). Semantic Syntax. Oxford: Blackwell. 
Van Bakel, Jan (1975). Automatische zinsontleding met de computer. Nijmegen: Dept. of Computational Linguistics.

- (1984). Automatic Semantic Interpretation. Dordrecht: Foris.

Vanden Wyngaerd, Guido (1989). Verb projection raising and the status of infinitival complements. In Sentential Complementation and the Lexicon, Dany Jaspers, Wim Klooster, Yvan Putseys, and Pieter Seuren (eds.). Dordrecht: Foris.

Van Dreumel, Simon (1996). Subcategorisatie. Een onderzoek naar subcategorisatie en de verwerking ervan in een NLP-systeem. Unpublished Ms. thesis, University of Nijmegen. http://lands.let.kun.nl/TSpublic/dreumel/ma_thesis.en.html

- (2000). The Amazon grammar and the last part of the middle field. In Computational Linguistics in the Netherlands 1998, Selected Papers from the Ninth CLIN Meeting, Frank Van Eynde, Ineke Schuurman, and Ness Schelkens (eds.), 93-107. Amsterdam and Atlanta: Rodopi. http://lands.let.kun.nl/literature/dreumel.2000.1.ps

-; and Potjer, Jasper (1998). De Amazon-Grammatica. Technical Report CSI-R9823. University of Nijmegen: Computing Science Institute. http://lands.let.kun.nl/TSpublic/ dreumel/amazon.en.html

Van Zonneveld, Ron (1998). Soorten partikelverplaatsingen. Tabu 28(2), 57-71.

Zwart, Jan-Wouter (1993). Dutch syntax: a minimalist approach. Unpublished Ph.D. dissertation, University of Groningen. 